\title{
Select bibliography
}

\section{Archival material held at}

Arbeider bevegelsens Arkiv og Bibliotek, Oslo (ARBARK)

Archiv der Sozialen Demokratie der Friedrich-Ebert-Stiftung, Bonn (AsdD)

Archiv für die Geschichte der Soziologie in Österreich, Graz (AGSÖ)

BBC Written Archives Centre, Caversham (BBCWAC)

Bibliotheek van het Vredespaleis, The Hague (VP)

Bodleian Library, Oxford (BLO)

Columbia University Rare Books and Manuscript Library, New York

Deutsche Nationalbibliothek, Frankfurt am Main (DNB)

Deutsches Literaturarchiv, Marbach (DLA)

Geheimes Staatsarchiv Preußischer Kulturbesitz, Berlin (PK)

Home Office, London (HO)

Institut für Zeitgeschichte, Munich (IfZ)

Lambeth Palace Library, London

Politisches Archiv des Auswärtigen Amtes, Berlin (AA)

Schweizerisches Bundesarchiv, Berne (SBB)

Staatsarchiv des Kantons Basel-Stadt (StAB)

Stiftung Archiv der Parteien und Massenorganisationen der DDR im Bundesarchiv,

Berlin-Lichterfelde (SAPMO-BArch)

The National Archives, Kew (TNA)

And papers in the private possession of Ernest Rodker and Edna Sovin.

\section{Publications}

Andrew, Christopher, Secret Service: The Making of the British Intelligence Community, London: Heinemann 1985.

Andrew, Christopher, The Defence of the Realm: The Authorized History of MI5, London: Allen Lane 2009.

Barnes, James J. and Patience P. Barnes, Nazi Refugee Turned Gestapo Spy: The Life of Hans Wesemann, 1895-1971, Westport/London: Praeger 2001.

Barnes, James J. and Patience P. Barnes, Nazis in Pre-War London 1930-1939: The Fate and Role of German Party Members and British Sympathisers, Brighton/ Portland: Sussex Academic Press 2005. 
Bearman, Marietta, Charmian Brinson, Richard Dove, Anthony Grenville and Jennifer Taylor, Out of Austria: The Austrian Centre in London in World War II, London: Tauris Academic Studies 2008.

Berthold, Werner and Brita Eckert, eds, Der deutsche PEN-Club im Exil 1933-1938: Eine Ausstellung der Deutschen Bibliothek Frankfurt am Main, Frankfurt a. M.: Buchhändler-Vereinigung 1980.

Bower, Tom, The Perfect English Spy: Sir Dick White and the Secret War 1935-90, London: Heinemann 1995.

Brinson, Charmian, The Strange Case of Dora Fabian and Mathilde Wurm: A Study of German Political Exiles in London during the 1930s, Berne: Peter Lang 1997.

Brinson, Charmian, 'The Gestapo and the German Political Exiles in Britain during the 1930s: The Case of Hans Wesemann - and Others', German Life and Letters, 51, 1 (January 1998), 43-64.

Brinson, Charmian and Richard Dove, Politics by Other Means: The Free German League of Culture in London 1939-1945, London: Vallentine Mitchell 2010.

Brinson, Charmian and Richard Dove, 'Friends and Enemies: The Freier Deutscher Kulturbund and the British, 1938-1946', ANGERMION, 5 (2012), 135-45.

Broda, Paul, Scientist Spies: A Memoir of My Three Parents and the Atom Bomb, Kibworth Beauchamp: Matador 2011.

Brown, Andrew, 'The Viennese Connection: Engelbert Broda, Alan Nunn May and Atomic Espionage', Intelligence and National Security, 24, 2 (April 2009), 173-93.

Buresova, Jana, 'The Czech Refugee Trust Fund in Britain, 1939-1950', in Charmian Brinson and Marian Malet, eds, Exile in and from Czechoslovakia during the 1930s and 1940s: Yearbook of the Research Centre for German and Austrian Exile Studies, vol. 11, 2009, pp. 133-45.

Burke, David, The Spy Who Came in from the Co-op: Melita Norwood and the Ending of Cold War Espionage, Woodbridge: Boydell Press 2008.

Cesarani, David and Tony Kushner, eds, The Internment of Aliens in Twentieth Century Britain, London: Cass 1993.

Curry, John Court, The Security Service 1908-1945: The Official History, London: Public Record Office 1999.

Dove, Richard, Journey of No Return: Five German -Speaking Literary Exiles in Britain, 1933-1945, London: Libris 2000.

Dove, Richard, 'Gerhard Hinze or Gerard Heinz? A Life in Two Acts', in Charmian Brinson and Richard Dove, eds, German-Speaking Exiles in the Performing Arts in Britain after 1933: Yearbook of the Research Centre for German and Austrian Exile Studies, vol. 14, 2013, pp. 61-86.

Fox, John P., 'Nazi Germany and the German Emigration to Great Britain', in Gerhard Hirschfeld, ed., Exile in Great Britain: Refugees from Hitler's Germany, Leamington Spa: Berg 1984, pp. 29-62.

Haynes, John Earl, Harvey Klehr and Alexander Vassiliev, Spies: The Rise and Fall of the KGB in America, New Haven/London: Yale University Press 2009.

Hennessey, Thomas and Claire Thomas, Spooks: The Unofficial History of MI5, Stroud: Amberley 2009.

Heumos, Peter, Die Emigration aus der Tschechoslowakei nach Westeuropa und dem Nahen Osten, 1938-1945, Munich: R. Oldenbourg Verlag 1989. 
Hiller, Kurt, Rote Ritter: Erlebnisse mit deutschen Kommunisten, Gelsenkirchen: Ruhr Verlag 1951.

Jeffery, Keith, MI6: The History of the Secret Intelligence Service 1909-1949, London: Bloomsbury 2010.

Kapp, Yvonne and Margaret Mynatt, British Policy and the Refugees, 1933-1941, London/Portland: Frank Cass 1997.

Kuczynski, Jürgen, Memoiren: Die Erziehung des J.K. zum Kommunisten und Wissenschaftler, Berlin/Weimar: Aufbau, 2nd edition 1975.

Laemmel, Josef Otto, Das Unzerstörbare: Eine Art biographischer Roman, Vienna: Heimatland-Verlag 1981.

Lafitte, François, The Internment of Aliens, Harmondsworth: Penguin 1940. Republished London: Libris 1988 with a new introduction by the author.

London, Louise, Whitehall and the Jews 1933-1948: British Immigration Policy and the Holocaust, Cambridge: Cambridge University Press 2000.

Lützenkirchen, Harald, ed., Kurt Hiller: Die Rundbriefe des Freiheitsbundes deutscher Sozialisten, London 1939-1947, Fürth: Klaussner 1991.

Meyer, Ernst H., Kontraste, Konflikte: Erinnerungen, Gespräche, Kommentare, Berlin: Verlag Neue Musik 1979.

Pincher, Chapman, Treachery: Betrayals, Blunders and Cover-ups: Six Decades of Espionage, Edinburgh: Mainstream 2011.

Putlitz, Wolfgang zu, The Putlitz Dossier, London: Allan Wingate 1957.

Rimington, Stella, Open Secret: The Autobiography of the Former Director-General of MI5, London: Hutchinson 2001.

Röder, Werner, Die deutschen sozialistischen Exilgruppen in Großbritannien 1940-1945: Ein Beitrag zur Geschichte des Widerstandes gegen den Nationalsozialismus, Hanover: Verlag für Literatur und Zeitgeschehen 1969.

Seyfert, Michael, Im Niemandsland: Deutsche Exilliteratur in britischer Internierung, Berlin: Das Arsenal 1984.

Sherman, A. J., Island Refuge: Britain and Refugees from the Third Reich 1933-1939, 2nd edition, London: Frank Cass 1994.

Smith, Michael, Foley: The Spy Who Saved 10,000 Jews, London: Hodder 1999.

Suschitzky, Wolf, ed., Edith Tudor-Hart: The Eye of Conscience, London: Nishen 1987.

Ustinov, Peter, Dear Me, London: Heinemann 1977.

Vansittart, Robert, The Mist Procession: The Autobiography of Lord Vansittart, London: Hutchinson 1958.

Wasserstein, Bernard, Britain and the Jews of Europe 1939-1945, Oxford: Clarendon 1979.

Weinstein, Allen and Alexander Vassiliev, The Haunted Wood: Soviet Espionage in America - The Stalin Era, New York: Modern Library, paperback edition 2000.

Werner, Ruth, Sonya's Report, London: Chatto and Windus 1991.

West, Nigel, MI5: British Security Service Operations 1909-1945, London: Bodley Head 1981.

West, Nigel and Oleg Tsarev, The Crown Jewels: The British Secrets at the Heart of the KGB Archives, London: Harper Collins 1998. 
West, Nigel, ed., The Guy Liddell Diaries, vol. 1 1939-1942, vol. 2 1942-1945, London: Routledge 2005.

Williams, Robert Chadwell, Klaus Fuchs, Atom Spy, Cambridge, Mass./London: Harvard University Press 1987.

Wright, Peter, Spycatcher: The Candid Autobiography of a Senior Intelligence Officer, New York: Viking 1987. 